\title{
Sosyal Yeterlilik, Sosyal Beceri ve Yaratıcı Drama
}

\author{
Fatma ÖNALAN AKFIRAT* \\ Milli Eğitim Bakanlığ 1
}

\begin{abstract}
Özet
Sosyal becerileri, bireyin toplum içerisinde diğerleriyle olumlu etkileșim kurmasımı sağlayan davranışlar; sosyal yeterliliği ise bu davranışların sergilenmesi ve başkalar tarafindan olumlu olarak değerlendirilmesi olarak tanımlayabiliriz. Sosyal beceri eğitimi, kökenleri sosyal ögrenme teorisine dayanan bir yaklaşmdir: Sosyal beceri eğitimi, sosyal becerilerin kazandırtlmastm amaçlayan, çoğunlukla davranış̧ tekniklere dayanan, performansa dayall, bireysel veya grupla uygulanan bir eğitim yöntemidir: Sosyal beceri eğitimi programlarl hazılanırken sosyal ögrenme, davranışı yaklaşım, bilişsel yaklaşım gibi yaklaşımlarm yöntem ve tekniklerinden yararlanlmaktadir: Sosyal beceri eğitiminde kullamilan bazl yöntem ve teknikler; model alma, liderlik, davranıssal prova-rol oynama, geribildirim verme, uygulama-genelleme, sosyal algl, duygular ve ev ödevi olarak ele almmaktadır: Yaratici dramanin, sosyal beceri eğitiminde kullanılan teknikleri kapsadı̆̆ ve sosyal beceri eğitiminde etkili bir yöntem olabileceği düşünülmektedir:
\end{abstract}

Anahtar sözcükler: Sosyal yeterlilik, sosyal beceri, sosyal beceri eğitimi, yaraticı drama, sosyal beceri eğitimi yöntem ve teknikleri.

\begin{abstract}
We can define social skills as the behaviors that enable the individual to interact positively with the others. Social competency, on the other hand, means performing those behaviors that are evaluated positively by the others. Social skills training is an approach which has its origins in the social learning theory. It's a performance based training method aimed at helping individuals gain social skills; mostly based on behavioral techniques and utilized in groups or on individual basis. In the development of social skills programs, the methods and techniques of such approaches as social learning theory, behavioral approach and cognitive approach are utilized. Some methods and techniques used in social skills training are modeling, leadership, behavioral rehearsal-role playing, feedback, practice-generalization, social perception, emotions and homework. It is considered that creative drama comprises the techniques used in social skills training.
\end{abstract}

Keywords: Social competency, social skills, social skills training, creative drama, methods and techniques of social skills training 
Çocuklar sosyalleşme süreci içerisinde kültürü öğrenir ve toplumun bir üyesi haline gelirler. $\mathrm{Bu}$ süreç doğumla başlar, ailenin çevre ve toplum konusunda verdiği bilgilerle sürer. Sosyalleşme süreci içerisinde birey kendini ve başkalarını gözleyerek, değişik yer, zaman ve durumlarda nasıl davranması gerektiğini ve günümüzde yaşam becerileri dediğimiz becerileri öğrenir. Bir diğer deyişle toplum içerisinde yaşamını sürdürebilmesi için bireyin bazı becerileri gösterebilmesi yani sosyal yeterliliğinin olması gerekir (Hops, 1983; Sukerman, 2000). Sosyal yeterlilik kavram1 genellikle sosyal beceri kavramı ile eş anlamlı olarak kullanılsa da sosyal beceriyi de kapsayan çok daha geniş bir kavramdır. Sosyal yeterlilik, bireyin belli bir durumdaki performansının genel niteliği konusunda sosyal yargıyı belirtirken, sosyal beceri belirli bir sosyal durumda yapilan davranıştır. Sosyal yeterliliği olan bireyin sosyal becerilere de sahip olduğu kabul edilir, fakat bazen bireylerin sahip oldukları bu becerileri nerede ve nasıl kullanacaklarını yeterince öğrenememiş olmaları sosyal beceri yetersizliklerini doğurmaktadır (Hops, 1983).

Çocukların ve ergenlerin sosyal yeterliliklerini belirlemeye ve sosyal beceri eksikliklerini gidermeye yönelik yapılan araştırmalar son yıllarda hız kazanmıştır. Sosyal beceri eğitimi, kökenleri sosyal ögrenme teorisine dayanan bir yaklaşımı içerir. Sosyal beceri eğitimi, sosyal becerileri veya sosyal yeterliliği yapılandırılmış ve sistematik bir tarz içerisinde öğretmeyi temel alır. Farklı sosyal durumlarda insanların uygun davranım yollarını kullanmasını ve geçerli alternatif tepkiler göstermesini amaçlar (Clark ve Fullwood, 1994).

\section{Sosyal Yeterlitik}

Sosyal yeterlilik kavramını sosyal beceriden ayırt etmek her zaman kolay olmamaktadir. Sosyal yeterlilik ve sosyal beceri kavramlarının sıklıkla birbirlerinin yerine kullanılmasına rağmen bu iki kavramın çok boyutlu, birbiriyle ilişkili ve aynı zamanda bağımsız yapılar olduğu belirtilmektedir (Bacanl,, 1999; Elliott ve Gresham, 1993; Merrel ve Gimpel, 1998).
McFall'a (1982) göre sosyal beceriler, bireylerin toplum tarafindan verilen görevleri/rolleri tamamladığını göstermesi için sergilemesi gereken belirli davranışlardır. Sosyal yeterlilik ise, kişinin görevlerini/rollerini yeterli bir şekilde yaptığını gösteren sonuç ve yargılamaya dayanan değerlendirmelerdir. $\mathrm{Bu}$ yargilar genel olarak başkalarının fikirlerine (arkadaş, aile, öğretmen) veya norm grubuna ya da başka bir ölçütle karşılaştırma yapılmasına dayanır.

McFall (1982), sosyal yeterliliğin özelliklerini şöyle ele almaktadır:

- Yeterlilik, bireyin performansının başkaları tarafindan değerlendirilmesidir. "Iyi", "uygun", "etkili" gibi terimler yeterliliğin yerine kullanılabilir.

Yeterlilik başkaları tarafından yapılan bir değerlendirme olduğundan dolayı ön yargılara ve hatalara açıktır. Aynı kriterlere göre farklı kişiler farklı değerlendirmelerde bulunabilirler.

- Değerlendirme her zaman belli bir ölçüte göre yapılacağından ölçüte karar verilmesi gerekir.

Yeterlilik her zaman duruma veya ölçüte göre değerlendirilir. Bundan dolayı durumlardaki ya da görevlerdeki çeşitlilik bireyin performansının yeterli olarak değerlendirilip değerlendirilemeyeceğini etkiler.

Bireyin özellikleri, yaş, cinsiyet, deneyim gibi faktörler değerlendirmeyi etkileyebilir.

Yeterlilikte tutarlllıktan söz edilebilir. Yeterli olarak değerlendirilen bir görev benzer koşullarda, farklı zamanlarda yine yeterli olarak yapılabilir.

Genel bir yeterlilikten değil belli bir görevdeki yeterlilikten söz eden McFall'in tersine Gresham ve Reschly (1988) sosyal yeterliliği sosyal beceriyi de içeren daha geniş bir yapı olarak ele almaktadır. Gresham ve Reschly (1988), sosyal yeterliliğin iki boyutu olduğunu belirtmektedir: Uyumsal Davranış (bağımsız işlev, fiziksel 
gelişim, akademik beceriler, öz- denetim, kişisel sorumluluk, ekonomik-mesleki etkinlik) ve sosyal beceriler (Akademik performans, katılımcı davranışlar, sosyal girişim davranışları, atılgan davranışlar, akranlara yönelik pekiştirici davranışlar, iletişim becerileri, sorun çözme becerileri, sosyal özyeterlilik). Uyumsal davranış ve sosyal beceriler arasında en az orta düzeyde bir ilişki bulunmaktadır. Sosyal beceri düzeyi yüksek olan bireyin, günlük yaşam gerekliliklerini yerine getirebildiği, kendisi ve başkaları için katılım ve sorumluluk gerektiren durumlarda başa çıma davranışları gösterebildiği varsayılmaktadır. Sosyal beceri düzeyi düşük olan birey ise yaşam gerekliliklerini yerine getiremez, başkaları veya kendisi için sorumluluk geliştiremez.

Gresham (1986) sosyal yeterliliğe üçüncü bir alt boyut olarak "akran kabulünï" eklemiştir. Akran kabulü hem sosyal yeterliliğin bir parçası hem de yeterli sosyal davranışların bir sonucudur. Yani akran kabulü sosyal yeterlilik altında uyumsal davranış ve sosyal becerilerden ayrı bir boyut, aynı zamanda bu iki parçanın yeterli düzeyde olmasının sonucu olarak görülmektedir.

Merrell (1999) ise uyumsal davranışı daha kapsamlı olarak ele almakta, uyumsal davranışın sosyal yeterlilik ve sosyal becerileri kapsadığını; sosyal becerilerin de akran ilişkileri ile ilişkili olduğunu vurgulamaktadır. Akran ilişkilerinin uyumsal davranışın ögesi değil, bireyin sosyal becerilerinin bir ürünü olduğunu belirtmektedir.

Diğer bir sosyal yeterlilik tanımı ise öğrencilerin yeterlilik düzeyleri göz önüne alınarak yapılmıştır. Knapczyk ve Rodes (1996) sosyal yeterliliği, ögrencilerin ortalama bir sosyal yeterlilik düzeyine erişebilmeleri için geniş bir davranış örüntüsüne sahip olmaları şeklinde değerlendirmişlerdir. Sosyal yeterlilik öğrencilere, sosyal etkileşimlerinde başarılı olmalarını sağlayan davranışların, yargıların ve algıların sınırsız donanımını sağlar. Knapczyk ve Rodes (1996) selamlama, sınıf arkadaşlarıyla konuşma, davranışlara olumlu ve olumsuz tepkiler verme, çevresindeki insanların övgü ve eleştirilerini kabul etme, kızdırmaya, takılmaya ya da kü- çültücü eleştirilere cevap verme, okul arkadaşlarının saldırgan davranışlarıyla başa çıkma davranışlarını gösteren öğrencileri sosyal yeterliliğe sahip olarak nitelemişlerdir.

Sosyal yeterlilik, jest ve mimik kullanma, vücut dilini yorumlama, o an gelișen durumlar hakkında sınıf içinde konuşma ve tartışmaya katılma gibi hem sözel hem de sözel olmayan davranışları içerir. Bu davranışları doğru olarak kullanma becerisi, öğrencilerin sosyal yeterliliklerini belirler. Sosyal yeterlilik, sosyal beceriler kavramından daha geniş ve kapsaml bir terimdir. Çünkü sosyal yeterlilik sadece farklı hareket ve becerilere karşılık gelmez. Aksine, öğrencilerin etkileşimlerinde gösterdikleri davranışların tüm özellik ve uygunluğunu kapsar. Sosyal yeterlilik göstermede ögrencilerin yeterli olmak zorunda oldukları bireysel beceri ve faaliyetler; konuşmayı başlatma, başkalarına destek olma, uyum gösterme, etkileșimi devam ettirme ve istemediği bir şeyi yapmama gibi davranışlardır. Bu beceriler öğrencilerin sosyal olarak kabul edilebilir olmalarına ve kişisel olarak doyurucu etkileşimde bulunmalarma izin verir (Knapczyk ve Rodes, 1996; Korinek ve Popp, 1997).

Coleman (1992) ise, sosyal yeterliliğin, sosyal beceriler, duygusal faktör ve kendini kontrol etme alt boyutlarından oluştuğunu belirtmektedir. Sosyal becerilerin diğer insanlarla etkili bir iletişim kurmak için kullanıldığı, bu becerilerin konuşmayı başlatma gibi sözel, bağımsız çalışma gibi sözel olmayan veya bilișsel becerileri içerdiği belirtilmektedir. Sosyal beceriler, kişinin kişisel haklarını savunabilmesini, kendisine ters gelen istekleri geri çevirebilmesini, gerektiğinde başkalarından yardım isteyebilmesini kolaylaştırabilmektedir (Sorias, 1986).

Schneider (1993) ise davranışsal boyutu ve akran kabulïnï içeren bir sosyal yeterlilik tanımı yapmıştır. Sosyal yeterlilik bireyin, insanlararası ilişkilerini başkalarına zarar vermeden yürütmesi ve gelişimsel olarak uygun olan sosyal davranışlar ortaya koyma yeteneği olarak tanımlamaktadır. Yeterlilik, davranışın nasıl olacağını gösteren zihinsel haritalardan çok, davranışı 
gerçekten yapabilmeyi gerektirir. Örneğin, bir çocuk nasıl arkadaşlık kurulacağını biliyor ama yapamıyorsa sosyal olarak yeterli kabul edilemez. Sosyal yeterlilik aynı zamanda akranların ya da birey için önemli olan kişilerin kabulü tarafindan da şekillenir. Bu nedenle, yakın ilişki ya da sosyal destek gereksinimini karşılayan birey sosyal olarak yeterlidir. Bireyin ilişki kurmada ve bu ilişkileri sürdürmede de yeterli olması gerekir. Sosyal yeterliliği oluşturan ise özel ve ayrı olan sosyal becerilerdir. Sosyal beceriler, bireyin davranışını zihinsel haritasıyla koordine edebilmesini sağlayan öz denetim becerilerini, belli davranışları ne zaman yapabileceğini belirlemesini ve onlar arasından seçim yapmasını sağlayan sosyal-algısal ve sosyal-bilişsel becerileri ve bir sosyal durumda ne yapacağının bilgisini kapsamalıdir.

Görüldüğï gibi sosyal yeterlilik ve sosyal beceri kavramlarını ayırmak oldukça zordur ve bu kavramlar iç içe geçmiş durumdadır. Bacanlı'ya (1999) göre, sosyal yeterliliğin, sosyal becerinin değerlendirilmesi ve bu değerlendirme sonucunda kişinin gelecek davranışları hakkında ipuçları veren ve davranışlarda tutarlılığı varsayan bir kavram olarak ele alınması uygun görülmektedir.

\section{Sosyal Beceriler}

İçinde bulunulan sosyal ortama uygun davranma yeteneği olarak tanımlanan sosyal beceriler, doyum verici (kişiler arası ilişkilerin kurulmasında ve sosyal amaçların gerçekleştirilmesinde çok önemli bir rol oynar (Sorias, 1986). Bacanlı (1999) sosyal becerinin ne olduğu, nelerden (hangi ve nasıl davranışlardan veya becerilerden) oluştuğu, özelliklerinin veya şartlarınm neler olduğu hususunda bir uzlaşma sağlanabilmiş olmadığını belirtmektedir. Sosyal yeterlilik gibi sosyal becerilerin de uzmanlar tarafından farklı tanımlarının yapıldığı ve karmaşık bir kavram olduğu görülmektedir.

Gresham ve Reschly (1988), literatürde yer alan sosyal beceri tanımlarını üç başlıkta sınıflandırmışlardır. Bunlar akran kabulü tanımı, davranışsal tanım ve sosyal geçerlilik tanımıdır. Akran kabulü tanımı, araştırmacıların akranlar tarafindan kabul edilmeyi ya da popülerliği sosyal becerinin göstergesi olarak aldıkları tanımdır. Akranları tarafindan kabul gören veya popüler olan çocuk veya ergenlerin sosyal becerilere sahip oldukları varsayılmaktadır. Ancak bu tanım hangi davranışların akran kabulünü veya popülerliği sağladığını belirleyememektedir. Davranışsal tanım, sosyal becerinin kişinin sosyal davranışının pekiştirilme olasılığını artıran ya da cezalandırılma olasılığını azaltan duruma özel davranışlar olarak kabul edildiği tanımdır. Bu tanımla belli sosyal davranışların öncesi ve sonuçları değerlendirme ve iyileştirme amacıyla belirlenmiş ve işlevsel hale getirilmiş olmaktadır. Sosyal geçerlik tanımı ise, sosyal beceriyi, çocuğun belli durumlarda, önemli sosyal durumları tahmin etmesine yardımcı olan davranışlar olarak ele alır. Bu önemli sonuçlar ise; akran kabulü ya da popülerlik, önemli kişilerin çocuğun sosyal becerileri hakkındaki yargıları, akran kabulü ve önemli kişilerin yargılarıyla ilişkili olan diğer sosyal becerilerdir.

McFall (1982), literatürde sosyal beceri kavramına yönelik iki temel model (özellik modeli ve moleküler model) olduğunu belirtmektedir. Özellik modeline göre sosyal beceri, temel bir kişilik özelliği anlamına gelen varsayımsal bir yapıdır. Bu model, sosyal becerilerin doğrudan gözlenemeyeceğini, ayrıca bireyin davranışını, onun sosyal beceri düzeyinin yalnızca bir yansıması olduğunu belirtmektedir. Bireyin sosyal beceri düzeyi, herhangi bir sosyal durumda sergilediği performansla doğru orantılıdır. Bu yaklaşımın temel varsayımı, bireyin sosyal beceri düzeyinin statik olduğu ve farklı durumlardaki becerilerin birbiriyle oransal olarak tutarl olacağıdır. Moleküler yaklaşım ise sosyal beceriyi, gözlenebilir özel davranış birimleri olarak ele almaktadır. Bu davranış birimleri, bireyin kişiler arası durumlardaki performansının temelini oluşturmaktadır. Özellik yaklaşımının tersine, moleküler yaklaşım sosyal becerinin dinamik olduğunu ve becerilerin zamana ve duruma göre değişeceğini varsaymaktadır.

McFall (1982) özellik ve moleküler modelleri eleştirirken, bilişsel ağırlıklı üç sistem yaklaşımı 
adımı verdiği kendi modelini ortaya koymaktadır. Üç sistem yaklaşımı, bireyin sosyal performansının fizyolojik, bilişsel ve motor davranışlar temelinde değerlendirilebileceği varsayımına dayanmaktadır. Fizyolojik beceriler, tüm algısal işlemleri, otonom düzenleri ve denetimi kapsar. Fizyolojik etkinliklerini düzenleyebilme, bireyin sosyal beceriye sahip olarak değerlendirilip değerlendirilemeyeceğini belirlemede etkili olabilir. Bilişsel beceriler, bir görevi yerine getirme sürecinde, gelen uyarıcı bilgilerin davranışsal programlara dönüştürülmesini içerir. Motor beceriler ise kişilerarası etkileşimde önemli rol oynayan, sözel ve sözel olmayan davranışları içerir.

Riggio (1986) da duygusal alanların da bilişsel boyutunu öne çıkararak, bilişsel boyuta önem vermiştir. Bilginin alınmasının ve gönderilmesinin temel sosyal becerileri yansıttığını, sosyal becerilerin öğrenilmiş iletişim becerileri olduğunu, bu becerilerde gelişmenin bireyin sosyal ilişkilerinde etkili ve sağlıklı olmasinı sağladığını vurgulamaktadır. Riggio (1986) sosyal beceriyi çok boyutlu bir kavram olarak ele almaktadır. Bu boyutlar; duygusal ifade, duygusal duyarlılık, duygusal denetim, sosyal ifade, sosyal duyarlılık, sosyal denetim ve sosyal manipülasyondur.

\section{Duygusal İfade}

Duygusal ifade; sözel olmayan mesajları, duygusal durumları algilayarak duyguları uygun bir şekilde ifade etme becerisidir.

\section{Duygusal Duyarlılk}

Duygusal duyarlılık, başkalarından gelen sözel olmayan mesajları alabilme ve çözümleyebilme becerisidir. Duygusal duyarlılık becerisine sahip olan bireyler başkalarının durumlarını gözlemeye ilgili ve dikkatlidirler.

\section{Duygusal Denetim}

Duygusal denetim, duygusal göstergeleri ve sözel olmayan mesajları denetleyebilme ve düzenleyebilme becerisidir. Duygusal denetim bece- risi olan bireyler duygularını denetleyebilir ve gerektiğinde gizler, gerektiğinde iletebilirler.

\section{Sosyal İfade}

Sosyal ifade, başkalarıyla iletişimde sözel ifade ve sosyal etkileşimde bulunabilme becerisidir. Bu beceriye sahip olan bireyler dışa dönük, duygularını dışa vuran ve dost canlısı olanlardır.

\section{Sosyal Duyarlılık}

Sosyal duyarlılık, uygun sosyal davranış normları bilgilerine sahip olmayı ve sözel mesajları anlamayı içerir. Sosyal davranış becerisi yüksek olan bireyler uygun sosyal davranışa odaklandığından sosyal kaygıları yüksek olabilir. Kendi ve başkalarının davranışlarına karşı dikkatli ve özenli olurlar.

\section{Sosyal Denetim}

Sosyal kontrol, kendini sosyal olarak ortaya koyma ve ifade etme becerisidir. Sosyal kontrol becerisi yüksek olan bireyler, sosyal olarak uyumlu, kendine güvenli, sosyal rolleri oynamada beceriklidirler.

\section{Sosyal Manipülasyon}

Sosyal manipülasyon, beceri ve tutum olarak ele alınabilir. Sosyal manipülasyon becerisi olan bireyler sosyal ilişkilerinde zaman zaman başkalarını manipüle etmek gerektiğine inanırlar.

Riggio'ya (1986) göre daha çok sosyal beceriye sahip olmak avantaj ve istenen bir durum olarak görülebilir, ancak sosyal becerinin sadece bir boyutu ile sosyal etkililik arasında ilişki doğrusal olmayabilir. Örneğin sosyal ifade becerisi yüksek olan ama sosyal kontrolü olmayan bir birey, önceleri olumlu tepkiler alırken bir süre sonra boş ve fazla konuşan biri olarak algılanabilir. Bu nedenle bu boyutların birbiriyle bütünleşmesi ve dengeli bir şekilde kullanılması önemlidir.

Shepherd (1983) ise sosyal becerileri dört boyutta ele almıştır: 


\section{Bireyin kendisine ilişkin davranışlar:} Sonuçları kabul etme, ahlaki davranış, duyguları ifade etme, kendine karşı olumlu tutum, özbakım, sağduyulu davranma.

2. Çevreye ilişkin davranışlar: Çevresi ile ilgilenme, tehlikeyle başa çıma, çevresinde hareket etme.

3. Kişilerarası davranışlar: Otoriteyi kabul etme, dikkat toplama, başkalarına yardim etme, çatışmaları çözebilme, başkalarını selamlama, diğerlerine karşı pozitif tutum, mülkiyet fikri.

4. Görevle ilişkili davranışlar: Soru sorma, sorulara cevap verme, sınıf tartışmalarına katılma, bağımsız çalışma, grup etkinliklerine katılma, sorumluluklarını yerine getirme, kurallara uyma (Akt: Merrell ve Gimpell, 1998).

Calderella ve Merrell (1997), sosyal becerilerin boyutlarını ayrıntılı bir şekilde sınıflandırabilmek için araştırma yapmışlardır. Öncelikle kapsamlı alanyazın çalışması sonucunda çocuk ve ergenlerle yürütülmüş 21 araştırma belirlemişlerdir. $\mathrm{Bu}$ çalışmaların gözden geçirilmesi ve yapılan meta analizi sonucu çocuk ve ergen sosyal becerilerinde beş boyut saptamışlardır. $\mathrm{Bu}$ boyutlar ve kapsadıkları belirli beceriler şunlardir:

1. Akran İlişkili Beceriler: Arkadaşlarını takdir etme, arkadaşlarını oyuna davet etme, arkadaşlarıyla konuşma, tartışmalara katılma, arkadaşlarının haklarını savunma, liderlik yapma, arkadaşlık kurabilme, mizah anlayışına sahip olma.

2. Kendini Denetleyebilme Becerileri: Öfkesini kontrol etme, sorunlar karşısında soğukkanlı olma, kurallara uyma, uygun durumlarda uzlaşma, başkalarının eleştirilerini kabul etme, iyi eleştiriler alma.

3. Akademik Beceriler: Bağımsız olarak çalışabilme, bağımsız olarak görevlerini başarma, öğretmenin yönergelerini din- leme ve getçekleştirme, boş zamanlarını uygun bir şekilde kullanma, gerektiğinde yardım isteme.

4. Uyma Becerileri: Yönergelere uyma, kuralları izleme, eşyalarını paylaşma, ödevlerini yapma, sorumlulukların yerine getirme.

5. Atılganlık Becerileri: Başkalarıyla konuşmak için girişimde bulunma, arkadaşlarını oyuna davet etme, kendisi için güzel şeyler söyleme ve yapma, bilmediği kuralları sorma, kendini tanıtma, duygularını ifade etme, grup çalışmalarına katılma.

Michelson, Sugai, Wood ve Kazdin (1983), sosyal beceri konusunda yapilan on altı farklı tanımı incelemişler ve bu tanımların yedi ortak noktasını bulmuşlardır. Bu noktalar, sosyal beceriler öğrenme yoluyla kazanılmakta, sözel ve sözel olmayan davranışları içermekte, etkileşimi başlatma ve uygun tepkide bulunmayı sağlamaktadır. Bunun yanısıra bu becerilerin sosyal ödüllerle etkililiği artmakta, çevre ve birey etkileşimi sonucu oluşmakta, bireyin demografik özellikleri ile çevre etkileşimi sonucu ortaya çıkmakta, becerilerdeki eksiklikler değerlendirmelerle belirlenebilmekte ve eğitimle geliştirilebilmektedir (Akt.: Elliot ve Gresham, 1993). Merrell (1999) sosyal beceriyi tanımlarken davranışsal boyuta vurgu yapmakta ve sosyal beceriyi, bireyin sosyal olarak istendik sonuçlara ulaşmasını sağlayan özel davranışlar olarak tanımlamaktadır.

Westwood (1993) sosyal becerileri, bireylerin başkaları ile olumlu etkileşimi başlatma ve sürdürme için gerekli olan davranışlar olarak tanımlamakta; bu davranışların sosyal yeterlilik için önemli olan sözel ve sözel olmayan becerileri içerdiğini vurgulamaktadır. Bu davranışlar arasında: Başkalarıyla göz ilişkisi kurabilme, uygun yüz ifadesi kullanabilme, başkalarına karşı hissettiği yakınlığa göre uygun mesafede durabilme, uygun fiziksel dokunmayı kullanabilme, sesini uygun şekilde kullanabilme, selamlayabilme, 
yaşına uygun konuşabilme, soru sorabilme, sorulara uygun yanıtlar verebilme, başkalarıyla çalışabilme, oyuna katılabilme, yardım etme, özür dileme, sıraya girebilme, teşekkür edebilme, yardım isteyebilme, öfkesini kontrol edebilme, eleştirileri kabul edebilme, kıyafetine dikkat etme ve temiz olma yer almaktadir.

McGuire ve Priestly (1981) ise farkh bir sosyal beceri tanımı yapmışlar; becerileri yaşam becerileri ve sosyal beceriler olarak iki gruba ayırmışlardır. Yaşam becerileri, iş bulma, paranın kontrolü ve toplum içerisinde yaşayabilmek için gerekli olan karmaşık davranışlar olarak tanımlanmıştır. Sosyal beceri ise kişilerarasında etkili yüz yüze iletişime olanak sağlayan davranış biçimi olarak tanımlanmıștır. İki kavram arasında kesin bir ayrım yapmamışlar, ancak her iki becerinin de toplum içerisinde etkin olarak yaşayabilmemiz için gerekli olan önemli beceriler olduğunu belirtmişlerdir. McGuire ve Priestly (1981), bu becerileri: Kendi güdülerini anlama, kendi hedeflerini oluşturma, kendini değerlendirme gibi özfarkındalık becerileri; kendini anlaşllır bir konuşma ile ifade etme, dinleme, telefon kullanma, başkalarını anlama gibi etkileşim becerileri; karar verme, planlar yapabilme, alternatifler oluşturabilme gibi sorun çözme becerileri şeklinde üç gruba ayırmıştır.

Akkök (1999) ise sosyal becerileri altı grupta toplamakta, bu becerilerin sosyal yeterliliği sağladığını, bu becerileri kazanmanın akademik gelişimle iç içe olduğunu vurgulamaktadır.

\section{1. İlişkiyi Başlatma ve Sürdürme Becerileri}

- Dinleme

- Konuşmayı başlatma

- Konuşmayı sürdürme

- Soru sorma

- Teşekkür etme

- Kendini tanitma

- Başkalarını tanıtma

- Illtifat etme
- Yardim isteme

- Bir gruba katılma

- Yönerge verme

- Yönergelere uyma

- Özür dileme

- İkna etme

\section{Grupla Bir İşi Yürütme Becerileri}

- Grupta iş bölümüne uyma

- Grupta sorumluluğunu yerine getirme

- Başkalarının görüşlerini anlamaya çalışma

\section{Duygulara Yönelik Beceriler}

- Kendi duygularm anlama

- Duygularını ifade etme

- Başkalarının duygularını anlama

- Karşı tarafın kızgınlığı ile başa çıkma

- Sevgiyi, iyi duyguları ifade etme

- Korku ile başa çıkma

- Kendini ödüllendirme

4. Saldırgan Davranışlar ile Başa Çıkmaya Yönelik Beceriler

- İzin isteme

- Paylaşma

- Başkalarına yardım etme

- Uzlaşma

- Kızgınlığı kontrol etme

- Hakkını koruma, savunma

- Alay etmeyle başa çıkma

- Kavgadan uzak durma

\section{Stres Durumlariyla Başa Çıkma Becerileri}

- Başarısız olunan bir durumla başa çıkma

- Grup baskısıyla başa çıkma 
Utanılan bir durumla başa çıkma

Yalnız bırakılma ile başa çıkma

\section{Plan Yapma ve Problem Çözme Becerileri}

- Ne yapacağına karar verme

- Problemin nedenlerini araştırma

- Amaç oluşturma

- Bilgi toplama

- Karar verme

- Bir işe yoğunlaşma

Rinn ve Markle (1979) ise sosyal becerileri dört kategoride incelemişlerdir. Bu kategoriler: Duygu ve düşünceleri ifade etme, kendisi hakkında olumlu düşünceleri ifade etme gibi kendini anlatma becerileri; arkadaşlarına olumlu düşüncelerini ifade etme, başkalarının düşüncelerine katılma, başkalarını övme gibi çevresini genişletme becerileri; ricada bulunma, mantıksız istekleri reddetme gibi atılganlık becerileri; konuşma ve kişilerarası sorun çözme gibi iletişim becerilerinden oluşmaktadır (Akt.: Cartledge ve Milburn, 1983).

Alanyazında sosyal yeterlilik ve sosyal becerilere ilişkin farklı görüş ve tanımların olduğu görülmektedir.

\section{Sosyal Beceri Yetersizlikleri}

Sosyal beceri yetersizlikleri genel olarak dört gruba ayrılmaktadır (Elliot ve Gresham, 1987; Gresham, 1986; Gresham ve Reschly, 1988). Bu yetersizlikler:

\section{Sosyal Beceri Yetersizlikleri}

Sosyal beceri yetersizliği, çocuğun başkalarıyla uygun etkileşimde bulunabilmek için gereken sosyal becerileri kazanamamasindan ya da beceriyi uygulamada gereken bir adımı öğrenmede başarısız olmasından kaynaklanır. Örneğin işbirliği yapmayı, sohbeti başlatmayı bilmemesi gibi. Sosyal beceri yetersizliğini belirlemek için çocuğun davranış hakkında bilgisinin olup olmadığı ve o davranışı daha önce kullanıp kullanmadığı araştırılmalıdır. Sosyal beceri eksikliklerini gidermek için ögretme, model olma ve davranış provası gibi yöntemler kullanılmaktadır.

\section{Sosyal Performans Yetersizlikleri}

Sosyal performans yetersizliği, bireyin beceriyi nasıl yapacağını bilmesi ancak bunu uygun zamanda uygulayamamasıdır. Bireyin beceriyi uygulaması için firsatı veya yeterli motivasyonu olmayabilir. Performansın yetersizliğini belirlemek için bireyin beceriyi yapıp yapmadığını gözlemlemek gerekir. Örneğin, çocuk bir beceriyi evde yapıyor sınıf ortamında yapamiyorsa ya da geçmişte yaptığı bir beceriyi başka bir zamanda yapamıyorsa performansın yetersizliğinden söz edilebilir. Sosyal performans ögretiminde, akran inisiyatifi, duruma bağlı sosyal pekiştirme gibi yöntemler kullanılmaktadir.

\section{3. Öz denetim Sosyal Beceri Yetersizlikleri}

Özdenetim sosyal beceri yetersizlikleri, bireyin duygusal tepkilerindeki artış nedeniyle beceriyi öğrenememesinden ortaya çıkmaktadır. Birey kaygı, korku, fobi ve içgüdüsellik nedeniyle beceriyi öğrenemeyebilir. Sosyal kaygısı yüksek olan birey akranlarıyla uygun etkileşimde bulunmayı öğrenemeyebilir. Ögretme için duyarsızlaştırma, kendini pekiştirme ve kendini gözleme gibi yöntemler kullanılmaktadır.

\section{4. Öz denetim Sosyal Performans Yetersizlikleri}

Öz denetim sosyal performans yetersizlikleri olan bireylerin davranış birikimlerinde (repertuarlarında) özel sosyal beceriler mevcuttur, ancak davranışsal aşırılıklar ve sonucun kontrolündeki sorunlardan dolay1 beceriyi istendik düzeyde yapamazlar. Dürtüsel olan birey, başkalarıyla uygun etkileşimde bulunmayı bilir ancak dürtüsel tepkide bulunma şekli uygun olmadığından bunu çok sık denemeyecektir. Ögretmede uygun olmayan davranışın engellenmesi, uyarıcı kontrolü eğitimi ve uygun sosyal davranışın pekiştirilmesi gibi yöntemler kullanılmaktadır. 
Sosyal becerilerde yetersizlik yaşayan bireyler kısa ve uzun dönemde olumsuz sonuçlarla karşılaşabilirler. Bu olumsuz sonuçlar, özellikle ergenlikte ve yetişkinlikte daha ağır sorunlara yol açabilir. Sosyal beceri yetersizlikleri, yetişkinlikteki uyum sorunlarının önemli bir yordayıcısı olarak da görülmektedir. Sosyal becerilerin gelişiminin, zihinsel yeterlik, okul başarısı ve sonraki yetişkin uyumu ile ilişkili olduğu belirtilmektedir (Elliot ve Gresham 1987; Merrell, 1999; Ogilvy, 1994; Verduyn ve Forrest, 1990). Yapılan diğer çalışmalarda da sosyal beceri yetersizliğinin saldırganlık, uygun olmayan davranışlar (Sunhi, 1999; Verduyn ve Forrest, 1990), madde bağımlılığı ergen suçluluğu, akademik ve mesleki sorunlar (Hansen, Nangle ve Meyer, 1998) gibi olumsuz sonuçlara neden olduğu belirtilmektedir. Sosyal becerilerde yeterlilik ise sosyal destek (Cohen, Sherrod ve Clark, 1986), sosyal uyum (Dubow ve Tisak, 1989), akran kabulü, akademik başarı (Parke, Harsman ve Robert, 1998) gibi olumlu sonuçlar ortaya koymaktadır.

Sosyal beceri yetersizlikleri, bireyin çeşitli sosyal becerilere sahip olmamasından ya da sahip olup da uygun ortam veya durumlarda kullanamamalarından ortaya çımaktadır. Birey beceriyi uygun sosyal ortamda hiç kullanamıyorsa beceriyi kazanamamış olduğu düşünülebilir. Bandura (1969) bunu öğrenme eksikliği olarak ele almaktadır (Akt.: Gresham ve Elliot, 1987).

Sosyal becerilerin gelişimini, yaş, cinsiyet, sosyo-ekonomik düzey ve engelli olup olmama gibi etkenler etkilemektedir. Yaşla birlikte çocuklar kendilerini ifade ederken sosyal olarak kabul edilebilir yolları ögrenirler (Herbert, 1996). Yapılan çalışmalar yaş ile sosyal beceriler arasında olumlu bir ilişki olduğunu göstermektedir (Matson, Heinze, Helsel ve Kopperman, 1986; Tüy, 1999). Sosyal beceriler ve cinsiyet konusunda yapılan çalışmalarda, kızların erkeklere oranla daha fazla uygun sosyal davranışlar gösterdikleri bulunmuştur (Matson, Heinze, Helsel ve Kopperman, 1986; Riggio, 1986). Sosyoekonomik düzeyin de sosyal beceriler üzerinde etkisi olduğu belirtilmektedir (Erdoğan, 2002).
Okul öncesi dönemden başlayarak, çocukların hangi alanlarda sosyal beceri yetersizlikleri gösterdikleri saptanarak uygun eğitim programlarının geliştirilmesi ve uygulanması gerekmektedir.

\section{Sosyal Beceri Eğitimi}

Sosyal beceri eğitimi, sosyal becerilerin kazandırıImasını amaçlayan, çoğunlukla davranışçı tekniklere dayanan, performansa dayal, bireysel veya grupla uygulanan bir eğitim yöntemidir (Shepherd, 1983). Sosyal beceriler öğretilebilir davranışlardır ve çoğu, sorunlu veya engelli çocuklara, uygun bir eğitim süreci ile kazandırılabilir (Gresham, 1997). Yetersizliği belirlenmiş becerilerin sistemli bir şekilde kazandırılmasını amaçlayan sosyal beceri eğitiminde amaç, bireylerin etkileşim becerilerini geliştirmek, içinde yaşadıkları çevreye uyum sağlamalarına yardıncı olmak ve yaşam kalitelerini artırmaktır (McGuire ve Priestley, 1981).

Sosyal beceri yetersizliklerini gidermeye yönelik herhangi bir müdahale programının öncelikle belirlenen problemlere uygun olması ve belirlenmiş belli beceri yetersizliklerini öğretmeye yönelik olması gerekmektedir (Gresham, 1997; Merrell, 1999).

Çocuklara verilecek sosyal beceri öğretimi çocuğun gelişim durumunu dikkate almak ve ilerleme için gerekli performansları belirleyerek, programda bunlara yer vermek durumundadır (Bacanl1, 1999). Sosyal beceri ögrretiminde ilk adım olarak, öncelikle farklı değerlendirme teknikleri kullanarak bireyin ya da grubun sosyal becerilerdeki yetersizliklerinin, hangi becerileri kullandığının, çocuğun bireysel performansı doğrultusunda nereden başlanacağının ve önceliklerin belirlenmesi gerekmektedir (Merrell ve Gimpel, 1998; Westwood, 1993). Sosyal beceri yetersizlikleri ve çocuğun gereksinimleri belirlendikten sonra uygun eğitim programı geliștirilmelidir (Antia, Kreimeyer ve Eldredge,1993; Westwood, 1993).

Sosyal beceri eğitimi bireysel veya grupla yapilabilmektedir. Sinıf ortamında sınıf, bireysel 
veya grupla sosyal beceri eğitimi yapılabilmekte, grubun oluşturulmasında ortak sosyal becerilerde yetersizlikleri olan bireylerin yaşları temel alınmaktadır. Sosyal beceri eğitimi programları hazırlanırken sosyal öğrenme, davranışçı yaklaşım, bilişsel yaklaşım gibi yaklaşımların yöntem ve tekniklerinden yararlanılmakta ve hangi tekniklerin kullanılacağına sosyal beceri eğitimi verilecek bireylerin özelliklerine ve gelişimlerine bağh olarak karar verilmektedir (Merrell ve Gimpel, 1998).

Sosyal beceri eğitiminde kullanılan bazı yöntemler, model alma, liderlik, davranışsal provarol oynama, geribildirim verme, uygulamagenelleme, sosyal alg1, duygular ve ev ödevi olarak ele alınmaktadır (Cartledge ve Milburn, 1983; Cartledge ve Milburn, 1986; Gresham, 1988; Herbert, 1996; Kerr ve Nelson, 1989). Yaratıcı dramanın da bir yöntem olarak sosyal beceri eğitiminde kullanılabileceği belirtilmektedir (Barnes, 1998; De La Cruz, Rey, Lian ve Morreau, 1998; Freeman, Sullivan, ve Fulton, 2003; Gresham, 1988; İpek, 1998; Klapprott, 2001).

\section{Model Alma}

Öğretilmesi hedeflenen sosyal beceri bir başkası tarafindan doğru olarak yapılmakta ve bireyler doğru davranışı izleme olanağı bulmaktadırlar. Bandura (1977) sosyal becerilerin gözlem yoluyla öğrenildiğini, bireyin beceriyi öğrenebilmesi için önce uygun modeli gözlemesi, gözlediği davranışı unutmaması, beceriyi kendisinin yapması ve tekrar yapmak için güdülenmesi gerektiğini belirtmektedir (Akt.Gresham, 1988). Model almada amaç, bireye becerinin nasıl yapılacağını, nasıl taklit edileceğini ve sosyal durumlarda nasıl uygun tepkiler verileceğini göstermektir. Öncelikle bireye bir model gösterilir, bireyin davranışı prova etmesi sağlanır, bireye performansına ilişkin geri bildirim verilir ve gerçek sosyal ortamlarda uygulaması sağlanır (Cartledge ve Milburn, 1983; Herbert, 1996).

\section{Liderlik}

Çocuk ile lider öğretilecek beceri ile ilgili çocuğun anlaması amacıyla bir tartışma gerçek- leştirmekte ve çocuğun davranışı anlaması sağlanmaktadır. Daha sonra lider çocuğu bu davranışı yaparken gözlemekte ve çocuk bu davranışı deneme olanağı bulmaktadır. Denemeye ilişkin olarak lider, değerlendirme ve önerilerde bulunmakta ve tekrar deneme yapilmaktadır. Birey davranışta yeterli duruma gelince gerçek sosyal ortamlarda yapması sağlanmaktadır (Cartledge ve Milburn, 1983; Herbert, 1996).

\section{Davranussal Prova-Rol Oynama}

$\mathrm{Bu}$ eğitim, çocuğun hedeflenen davranışı yapabilmesi için yönlendirilmesini içermektedir. Çocuğa kendi yaşantısında olabilecek bir senaryo verilir ve bu senaryoyu rol arkadaşı ile canlandırması sağlanır (Cartledge ve Milburn, 1983; Herbert, 1996). Davranışsal provada amaç çocuğun hedeflenen beceriyi öğrenebilmesi için beceriyi tekrarlaması yani defalarca prova etmesidir. Beceri prova edilirken rol oynama tekniği kullanılmaktadır. Agran ve Wehmeyer (1999), rol oynama tekniğinin grup içinde uygulandığında hem rol oynayan ögrenci için hem de onu gözleyen ögrenciler için yararlı bir teknik olduğunu belirtmektedir. Rol oynama diğer tekniklere göre daha az yapılandırılmıştır, bu nedenle ögretmenin rehberlik yapması, rol oynamayı daha etkili hale getirmektedir. Bu bakımdan öğretmenin yaratıcı drama alanında eğitim almış olması önem kazanmaktadır.

\section{Geri Bildirim Verme}

Bu model, çocuğa yapmaya çalıştığı ve yapabildiği davranışla ilgili olumlu düşüncelerin iletilmesidir (Cartledge ve Milburn, 1983; Herbert, 1996). Rol oynarken çocuğa beceriyi doğru olarak sergileyip sergilemediğine ilişkin bilgi vermek olarak tanımlanan geri bildirim, çocuğun beceriyi öğrenmesini artırmaktadır (Kerr ve Nelson, 1989). Ödüllendirme, sözel olarak doğru yaptığımı belirtme şeklinde yapılan geri bildirimler doğru performansın hemen ardindan yapılıp açıklandığında becerinin öğrenilmesi kolaylaşmaktadır (Gresham, 1988).

\section{Genelleme-Uygulama}

$\mathrm{Bu}$ eğitim, öğretilmesi hedeflenen beceri çocuk tarafindan ögrenildiğinde veya gelişme 
sağlandiğında, becerinin gerçek yaşamda uygulanmasının sağlanmasıdır (Cartledge ve Milburn, 1983; Herbert, 1996). Çocuğun öğrendiği beceriyi farklı zaman, ortam ve durumlarda kullanabilmesi beceriyi öğrendiğini ve genelleyebildiğim gösterir (Gresham, 1988).

\section{Sosyal Algı}

Sosyal algı ile anlatılmak istenen, çocuğa sözel olmayan iletişim mesajlarının (mimikler, beden dili, ses tonu vb) ne anlama geldiğinin ve nasıl yorumlanacağının öğretilmesidir (Cartledge ve Milburn, 1983; Herbert, 1996).

\section{Duygular}

Çocuğa sosyal beceriler öğretilirken, insanların duyguların anlama ve duyguların insan davranışını yorumlamada nasıl kullanılacağının ögretilmesidir (Cartledge ve Milburn, 1983; Herbert, 1996).

\section{Ev Ödevi}

Ev ödevleri yoluyla bireye, yeni kazandığ davranışları gerçek yaşam koşullarında deneme şansı verilir. $\mathrm{Bu}$ da eğitim sırasında kazanılan davranışın bireyin yaşamına aktarımını sağlar. Ödev verilen sosyal beceri eğitim programlarmın daha iyi gelişme sağladığ belirtilmektedir (Dikmeer, 1997).

\section{Yaratıci Drama}

Yaratıcı drama, alan yazında sosyal becerilerin öğretiminde bir yöntem olarak önerilmektedir (Akın, 1993; De La Cruz, 1995; Freeman, Sullivan ve Fulton, 2003; Gresham ve Elliot, 1990; Hedahl, 1980; İpek, 1998; Kocayörük, 2000). Eisler ve Frederikson (1980) ve Bandura (1969), tüm sosyal etkileşimleri tarif etmek için sosyal becerilerin tek bir tanımı olmamasına rağmen, sosyal becerilerin tanımlanabilmesi için ortak özelliklerin gerekliliğine işaret etmişlerdir. Bu özellikler geniş bir aralıkta etkili sosyal tepkilerin gelişimi, sosyal normların farkındalığı, verilen bir duruma verilebilecek en uygun tepkiyi seçebilme yeteneği, doğru geri bildirimleri anlama yeteneği ve doğru geri bildirimleri davranışa dönüştürerek kullanabilme yeteneğini içerir.
Sosyal becerilerin öğretilmesinde değişik modeller önerilmektedir. Eisler ve Frederikson (1980) bu modellerin benzer eğitim süreçlerini kullanarak sosyal beceri ögretmeyi tasarladıklarını belirtmektedir. Sosyal beceri eğitimi tasarlayan programlarda ve modellerde kullanılan süreç genelde; tepkinin ögrenimi-model alma, tepkinin uygulanması-rol oynama, tepkinin şekillenmesigeribildirim ve bilişsel yeniden yapılanmadır (Akt.: Freeman, Sullivan ve Fulton, 2003). Yaratıcı drama yöntemi ile hazırlanan bir sosyal beceri eğitimi programında, model alma, rol oynama, geribildirim ve bilişsel yeniden yapılanma süreçlerinin yer alabileceği düşünülmektedir.

Yaratıcı dramada yaşanan deneyimler, öğretmen ve katılımcıların süreç içerisinde yaşadıkları ve katılımcıların gözleyerek başkalarını model alması ile tepki öğrenme gerçekleşir. Öğretmen, öğrencileri ekip çalışması ve işbirliğine hazırlamak ve rehberlik etmek için yönergeler kullanır. Ayrıca öğretmen, grup çalışmasında başkaları konuşurken dinlemeyi, konuşma sırası gelene kadar beklemeyi ve başkalarına yer verme gibi kuralları çok müdahale etmeden ortaya koyar ve hatırlatır, bu yönergelerle birlikte tepki öğrenimini de (durumlar karşısında uygun tepki verebilmeyi) sağlar.

Slade (1955), uygun tepki vermeyi öğrenmenin, öğrencilerin başkalarının uygun sosyal davranışlarını gözleyerek ve rol oynayarak ifade etmeleri, bunu canlandırmaları, planlamaları ve uygulamaları şeklinde gerçekleştiğini vurgulamaktadır (Akt:: Freeman, Sullivan ve Fulton, 2003). Yaratıcı dramada rol oynayanlar ve onları izleyenler dışında izleyici yoktur. Oynayanlar ve gözleyen katılımcılar durumları oynadıktan sonra değerlendirir, uygun bir şekilde eleştirirler ve daha başka neler olabileceğini konuşurlar (bilişsel yeniden yapilanma).

Yaratıcı dramada katılımcılar değişik durumlarda nasıl tepki verildiğini (tepki uygulamasdavranışsal prova) rol oynama ile gerçekleştirirler. Rol oynama ile katılımcılar değişik karakterler sergilerken, değişik durumlarla yüz yüze gelme, çatışma yaşama, kızgınlık duyma ve problem çözümü gibi deneyimlerle duygusal kontrolü 
de öğrenirler. Ayrıca katılımcılar, durumları dramatize ederek, hareketleri tartışarak ve değişik roller oynayarak değişik bir bakış açısı oluştururlar. Yaratıcı drama sürecinde, katılımcılar rol oynamaya katılım konusunda seçme şansına sahip olurlar, rol oynarken seyirci yoktur, rol oynama kendiliğinden gerçekleşir, rol oynama grup tarafindan onaylanır veya pekiştirilir. Rol oynama sirasinda grup aynı zamanda birbirini destekler, birbirini değerlendirir (Freeman, Sullivan ve Fulton, 2003).

Ward (1952), tepki şekillenmesinin arkadaşlar ve öğretmenin doğru geribildirimleriyle gerçekleştiğini belirtir. Öğretmen veya lider, öğrencilerin, rol oynarken veya etkinliklere katılırken gösterdikleri iyi çabaları farkeder ve onları över, cesaretlendirir (Akt.: Freeman, Sullivan ve Fulton, 2003).

Yaratıcı dramada öğretmen, öğrencileri başkalarıyla kıyaslayarak değerlendirmek yerine, öğrencilerin canlandırmalardaki dramatik hareketlerini, ekip çalışmasını ve zamanlamasını analiz eden değerlendirmeler yapar. Değerlendirmenin amacı canlandırmayı geliştirmektir. Pinciotti'ye (1993) göre yaratıcı dramanın, çocukların diğerleriyle olan ilişkilerinde nasıl hareket edeceğini ve nasıl düşüneceğini değiştirme potansiyeli vardır (Akt. Freeman, Sullivan ve Fulton, 2003). Yaratıcı dramada amaç çocuğun zihninde olanları ortaya koyabilmesi, büyümesi, olgunlaşması ve dünyayı başka bir gözle görebilmesidir. Çocuklar dramada canlandırmalar yaptıkça ve yaşam durumları konusunda planlar yapıp oynadıkça bir şeyler öğrenirler. Duygusal dünyasını keşfederken yaşamda bulunan durumları ve farklı karakterleri de keşfeder. Böylece kendine ve başkalarına karşı tutumlarını, davranışlarını gözden geçirme fursatı bulurken bilişsel yeniden yapılanma da sağlanmıs olur (Freeman, Sullivan ve Fulton, 2003).

Sosyal beceri eğitiminde kullanılan teknikler, model alma, liderlik, davranışsal prova-rol oynama, geri bildirim verme, uygulama-genelleme, sosyal algı, duygular ve ev ödevidir. Yaratıcı drama, genel olarak bu teknikleri kapsamakta, eğitimin bilişsel, duyuşsal ve davranışsal boyut- larını da içermektedir. Sosyal beceri eğitimini amaçlayan yaratıcı drama eğitim programlarında, ögretilen becerinin günlük yaşamda gözlenmesine, denenmesine dair ev ödevlerinin verilebileceği düşünülmektedir. Sosyal beceri eğitiminde kullanılan teknikler ve Yaratıcı Drama Yöntemi Yoluyla Sosyal Beceri Eğitimi aşamalarının karşılaştırılması (Akfırat, 2004) Tablo l'de verilmiştir.

Rol oynama ve doğaçlama gibi, oynayan ve gözleyen için yararlı teknikleri içeren yaratıcı drama, sosyal beceri eğitiminde kullanılan yöntem ve teknikleri kapsamakta, sosyal beceri eğitiminde bir yöntem olarak kullanılmakta ve sosyal becerilerin geliştirilmesinde drama yönteminin etkili olduğuna ilişkin çeşitli araştırmalar (Akfirat, 2004; Akın, 1993; Barnes, 1998; De La Cruz, 1995; Freeman, Sullivan ve Fulton, 2003; Gresham ve Elliot, 1990; Hedahl, 1980; İpek, 1998; Kocayörük, 2000; Miller, Rynders ve Scleinen, 1993) bulunmaktadir.

İnsan beynindeki iki yarı kürenin, belli başlı ayrımının, sol yarıkürenin ussal, soyut, kavramsal, mantıklı, ardışık ve dizisel düşünme biçimine sahip olması; sağ yarıkürenin ise sözel olmayan, ardışı olmayan, 1raksal, sezgisel, imgesel düşünme biçimlerini kullanması olarak belirtilmektedir. San'a (1996) göre eğitimde sol beyne yüklenmek, düşünme ve yaratma becerileri gelişmeyen bireyler yetişmesine yol açmakta; sağ ve sol beyin arasında dengenin kurulması, akademik bilgi kadar duyuşsal ve düşsel yaşantıların da geliştirilmesi gerekmektedir. Öğrenmeyi salt bilişsel olmaktan çıkarıp yaşantısal hale getirmek ve iki birim arasında denge oluşturmak için kullanılabilecek yöntemlerden biri de yaratıcı drama olarak gösterilmektedir. Öğrenmeyi yaşantısal hale getirmesi yaratıcı dramanın sosyal beceri eğitiminde kullanılabilir bir yöntem olduğunu göstermektedir.

San (1991) oyun pedagojisi, etkileşim pedagojisi, yaratıcı oyun, informal drama, gelişimsel drama, eğitsel drama, tiyatro pedagojisi, doğaçlama kavramlarıyla da ifade edilen yaratıcı dramayı, bir sözcüğ̈u, bir kavramı, bir davranışı, bir tümceyi, bir düşünceyi, bir yaşantryı ya da bir 


\section{Tablo 1}

Yaratıcı Drama ve Sosyal Beceri Eğitiminde Kullanılan Tekniklerin Karşılaş̧tırtlması

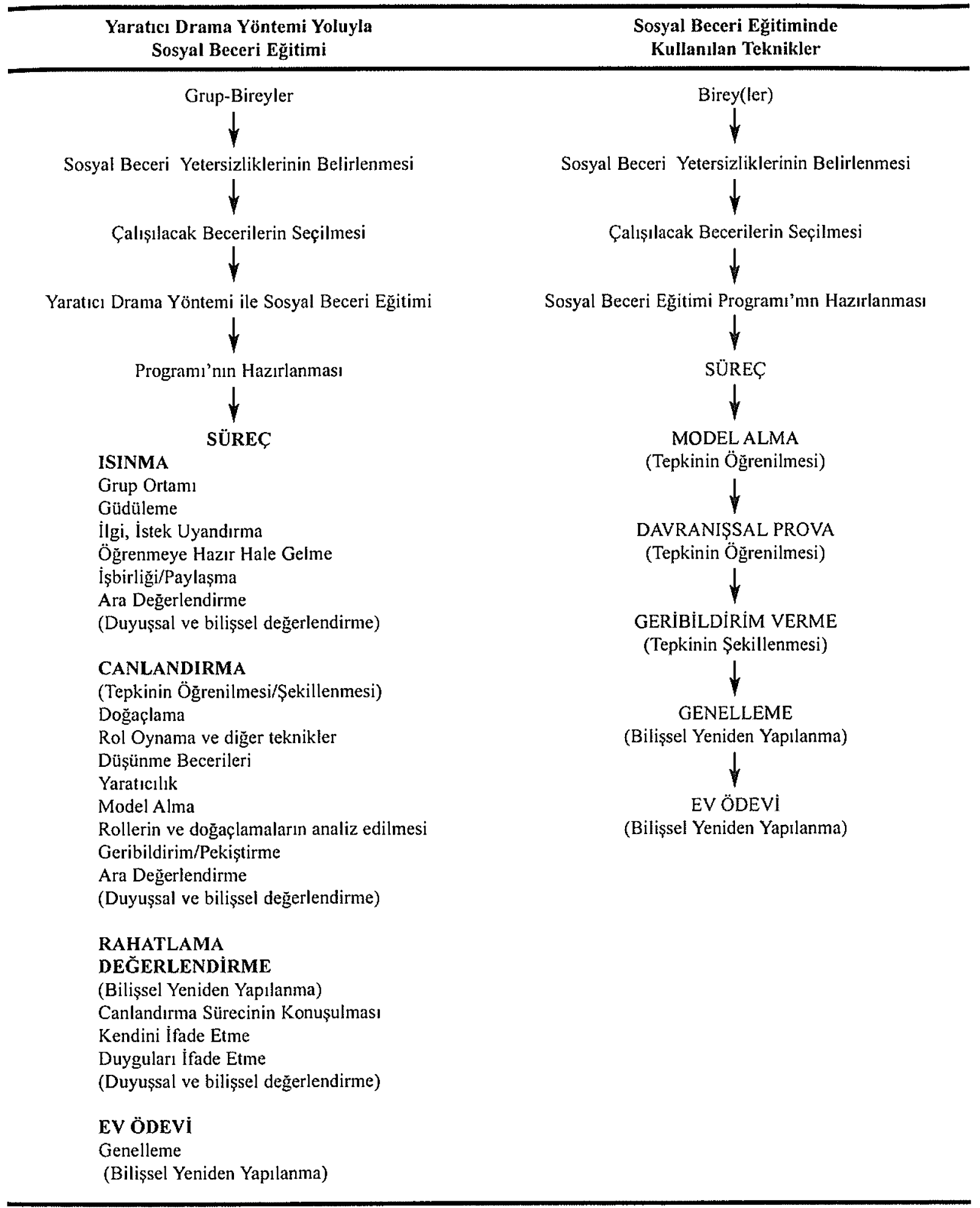

(Akfirat, 2004) 
olayı, tiyatro ve yaratıcı drama tekniklerinden yararlanarak, oyun veya oyunlar geliştirerek canlandırma olarak tanımlamaktadır. Bu canlandırmanın gerçekleştirilebilmesi için, grup içinde daha küçük gruplarla tartışarak düşünce alışverişi yapma, değerlendirme, yargılama, eleştirme gibi düşünsel boyutta çalışmaların yapılması da gereklidir. Grup tarafindan oluşturulan bu süreç ise sosyal beceri eğitimini de olanaklı kılmaktadır.

Yaratıcı drama, yaşamın modelini çıkardığımız ve yaşamı daha iyi anlamamızı sağlayan, katılımcıların kendilerinden farklı olan insanların sorunlarını ve değerlerini öğrendiğini, duyarlı oldukları rolleri üstlendikleri ve aynı zamanda bir grup içinde çalışmayı öğrendikleri, gözleyerek başkalarının aynı durumlarda neler yaptıklarını anlama olanağı buldukları ve pek çok sanatsal beceriyi de bir araya getiren bir süreçtir. Bu süreç içerisinde katılımcılar, rol oynama, rolleri analiz etme, dramatik etkinlikleri yaşama ve yorumlama, iş birliği yaparak ögrenme firsatı da bulmaktadırlar. Yaratıcı dramada bireyler verilen konu, tema, olay, model çerçevesinde rol oyunları oynamakta, doğaçlamalar yapmakta ve bunlar üzerinde değerlendirmeler yaparak var olanı ve olması gerekeni anlayabilmektedirler. Sosyal beceri tanımları ile yaratıcı drama tanımları ve amaçları incelendiğinde kazandırılmak istenen davranısların aslında sosyal beceriler olduğu görülmektedir.

Yaparak ve yaşayarak öğrenme olarak da tanımlanan yaratıcı dramanın genel amaçları özetle şöyle sıralanmaktadır (McCaslin, 1990; Ömeroğlu 1990):

- Yaratıcılık ve estetik gelişimi sağlama

- Eleştirel düşünme yeteneği geliştirme

- Sosyal gelişim ve birlikte çalışma becerisi geliştirme

- İletişim becerileri geliştirme

- Moral değerleri geliştirme

- Kendini tanima

- Problem çözme becerilerini geliştirme

- Dil becerilerini geliștirme

- Sanat anlayışı ve ruhunu kazandırma

- Hayal gücünü geliştirme

- Dinleme becerilerini geliştirme

- Olayları değerlendirme yeteneği kazandırma
- Insanların diğer insanlar, durumlar ve doğal

- Olaylar hakkındaki gözlemlerini geliştirme

- Bireylerde, grup planlaması, grupla karar verme,

- Yeni çözümler üretme yeteneği geliştirme

- Empati becerisi geliştirme

Yaratıcı drama çalışmalarının sağlayacağı yararlar ise şöyle belirtilmektedir (Adıgüzel, 1993; Akfirat, 2002; Barnes, 1998; Davies 1984; Gönen 1998; Gönen 2001; Jahanian, 1997; McCaslin, 1990; Ömeroğlu, 1992):

- Yaratıcı drama etkinlikleri bireye yeni ürünler ortaya koyma, başkalarıyla paylaşma ve kendini keşfetme olanakları sağlar.

- Çocuklar aynı zamanda gruplarla çalışma ve uslarında tasarladıklarını başkalarına anlatmayı öğrenirler.

- Sinıfta yapılan etkinlikler sınıf ruhunun ve arkadaşlık kavramının da pekişmesine yol açar.

- Yaratıcı drama teknikleri, gözlem becerilerini, bedensel ifade etmeyi, iletişim becerilerini ve yazılı dili anlama becerilerini geliştirir.

- Drama etkinlikleri sırasında katılımcılar hareket eder, pantomim yapar, doğaçlamalara katılır, şiir ve yazın türleri ile çalışır, şiir okur, şarkı söyler, resim yapar, yeni şeyler yaratır.

- Dil ve çok yönlü zeka teorileri eğitimde dramanın kullanımını desteklemektedir. Yaratıcı drama etkinlikleri ile hem çok yönlü zeka uygulamaları yaşama geçmiş olur hem de duygusal zeka gelişimi desteklenir.

Ayrıca drama ile sözel ifade becerileri gelişir. Okuma, okuduğunu anlama ve yazma becerileri gelişir,

- Düşünme yetenekleri gelişir.

- Hayal kurma becerilerini geliştirir.

- Soyut düşünme ve ortak anlama yeteneğ $i$ gelişir. 
- Akranlarla kaynaştırmayı kolaylaştırır.

- Sanata ilgiyi artırır.

McCaslin (1990) yaratıcı drama etkinliklerinin ortak hedefinin sosyal gelişme olduğunu vurgulamaktadır. Yaratıcı drama ilk önce insanın kendini anlama ve kabulünü daha sonra da başkalarını anlama, kabul ve paylaşmayı geliştirerek sosyal gelişimi sağlamaktadır. Özellikle yaratıcı drama, tehdit edici olmayan bir ortamda, katılımcılara duygusal rahatlama sağlayarak sosyal becerileri geliştirme olanağı vermektedir.

Yaratıcı drama katılımcılara yapıcı ve olumlu davranışları uygulama, öğrencilere iş birliği içinde birlikte çalışma fırsatı sunmaktadır. Bireylerin yaşadığı duygusal deneyimler, problem durumların keşfedilmesi ve çözüm yolları üretilerek duygusal kontrolün sağlanması ile giderek sosyal beceriler öğrenilir duruma gelmektedir (Freeman, Sullivan, ve Fulton, 2003).

Yaşayarak ögrrenme süreci olan yaratıcı drama etkinlikleri sırasında katılımcılar, kendini ve başkalarını tanımayı, aralarında benzerlik ve farklılıkları öğrenir. Grup içinde iş birliğini, paylaşmayı, ortak ve bağımsız düşünebilmeyi, eleştiri öz eleştiri yapabilmeyi öğrenir. Konuşma, dinleme, okuma, yazma becerilerini geliştirir. Farklı sosyal durumlarla ilgili deneyim kazanırken, farklı rollerde hissettiklerini anlamayı, anlatmayı, grup çalı̧̧maları içinde üretirken karar verme becerilerini, sorun çözme becerilerini öğrenir ve geliştirir. Yaratıcı drama sürecinde bu becerileri bireylerin yaratıcılıklarını kullanarak geliştirmesi önemlidir ve bu beceriler sosyal beceriler olarak adlandrrilmaktadir.

Yaratıcı drama, oyun yoluyla çocuğun yaşamında zaten yer almaktadır. Yaratıcı dramayı eğitimde kullanılan bir yöntem olarak ele aldığımızda, çocuklara öğretilecek konu veya becerilerin önceden belirlenmesi gerekmektedir. Böylece çocuk yaşayarak öğrenme sürecine aktif olarak katılacak, öğrenmeye ve araştırmaya istekli hale gelecektir. Yaratıcı drama yöntemi ile hazırlanacak sosyal beceri eğitimi programında sürecin iyi kurgulanması ve ögretilecek beceriye uygun yaratıcı drama aşamalarının planlanması gerekmektedir.
Günümüz eğitim sistemlerinde öğrenci merkezdedir ve yaratıcı drama, öğrenme ve öğretme sürecinde öğrencinin aktif katılımını sağlayan, yaparak ve yaşayarak öğrenmesine olanak veren yöntemlerden biri olarak görünmektedir. Öğrenci yaratıcı drama sürecinde bilişsel, duyuşsal ve devinişsel yaşantılar geçirme şansına sahip olmakta, sürece aktif olarak katıldığı için de öğrenme gerçekleşmektedir ve öğrenci bundan aynı zamanda zevk almaktadır.

Yaratıcı drama sahip olduğu pek çok özellik nedeniyle bilişsel, duyuşsal ve devinişsel becerilerin, diğer bir deyişle sosyal becerilerin öğretilmesinde etkin ve etkili bir öğretme ve öğrenme yöntemi olarak görünmektedir.

\section{Sonuç ve Öneriler}

Sosyal beceriler ile yaratıcı drama tanım ve amaçlarının örtüşmesine rağmen bu konuda yapılmış yeterince araştırma bulunmamaktadır. Yaratıcı drama yöntemi, grup çalışmasına olanak vermesi, okul öncesinden başlayarak tüm eğitim kademelerinde kullanılabilmesi ve ekonomik olması nedeniyle sosyal beceri eğitiminde etkin olarak kullanılması gereken bir yöntemdir. $\mathrm{Bu}$ nedenle;

Öğretmen yetiştirme programlarında sosyal beceri eğitiminin nasıl öğretileceği, yöntem ve teknikleri ders olarak yer almalıdır. $\mathrm{Bu}$, eğitim sistemimizde sosyal beceri eğitimini, öğretmenin keyfiyetine bırakmayı önleyecektir.

- Yaratıcı dramayı sosyal beceri eğitiminde kullanmak isteyen eğitimcilerin yaratıcı drama eğitimi almaları gerekmektedir.

- Sosyal beceri eğitiminde yaratıcı drama yöntemi kullanılmak isteniyorsa, çalışılacak grup daha önce yaratıcı drama ile tanışmamışsa, öncelikle yalnızca yaratıcı drama çalışmaları yapılmalı, daha sonra beceri eğitimine geçilmelidir.

- Sosyal beceri eğitimi ve yaratıcı drama arasında neden sonuç ilişkilerini irdelemeye yönelik araştırmaların yapılması alana katkıda bulunacaktır. 


\section{Kaynaklar}

Adıgüzel, Ö. H. (1993). Oyım ve yaratıct drama ilişkisi. Yayımlanmamıs yüksek lisans tezi, Ankara.: Ankara Üniversitesi.

Agran, M., \& Wehmeyer, M. (1999). Teaching Problem Solving To Students With Mental Retardation. Washington: American Association.

Akfırat, F. (2002). Bireysel farklılıkları olan çocuklar için drama lideri farklılıklar yaratabilir: İlköğretimde engelli ̧̧ocuklarla yaratıcı drama. N. Aslan (Ed), Ilkögrretimde Drama ve Tiyatro. Türkiye 4. Drama Liderleri Buluşması ve Ulusal Drama Semineri. Ankara: Olușum Tiyatrosu ve Drama Atölyesi Yayınları.

Akfirat, F. (2004). Yaratic dramamn issitme engellilerin sasyal becerilerinin gelişimine etkisi. Yayımlanmamı̧ doktora tezi, Ankara: Ankara Üniversitesi.

Akın, M. (1993). Farklt sosyo-ekonomik dïzeylerdeki ilkokul 3. simf öğrencilerinin sosyalleşme dïzeylerine yaratıc drama eğitiminin etkisi. Yayımlanmamış yüksek lisans tezi, Ankara: Ankara Üniversitesi.

Akkök, F. (1999). Ilköğretimde Sosyal Becerilerin Geliştirilmesi (Anne Baba El Kitabı). İstanbul: Milli Eğitim Basımevi.

Antia, S., K., \& Eldredge, K.H., (1993). Promoting social interaction between young children with hearing impairments and their peers. Exceptional Children, 60(30), 262-275.

Bacanh, H. (1999). Sosyal Beceri Eğitimi. Ankara: Nobel Yayınları.

Barnes, H. (1998). Identifying educational strategies for use with deaf pupils. The Journal of National Drama, $5(3), 20-25$.

Caldarella, P., \& Merrell, K. W. (1997). Common dimension of social skills of children and adolescent: A taxonomy of positive behaviors. Social Psychology Review, 26(2), 264-278.

Cartledge,G., \& Milburn,J.F. (1983). Social skills assessment and teaching in the schools. Advances in School Psychology, 3, 175-235.

Cartledge,G., \& Milburn,J.F. (1986). Teaching Social Skills To Children. New York: Pergaman Press.
Clark, P., \& Fullwood, L. (1994). Social skills activities to use with hearing impaired children. Jounal British Assn. Teachers of The Deaf, 18(3),86-94

Cohen, S., Sherrod, D.R., \& Clark. M.S. ( 1986). Social skills and stress-protective role of social support. Journal of Personality and Social Psychology, 50(5), 963-943.

Coleman, M.C. (1992). Behavior Disorders Theory And Practise. Boston: Allyn and Bacon.

Davies, D.G. (1984). Utilization of Creative Drama With Hearing -impaired Youth. The Volta Review, FebMar.

De La Cruz, R.E. (1995). The effect of creative drama on the social and oral language skills of children with learning disabilities. Unpublished Phd Dissertation, Illinois: Illinois State University.

De La Cruz, R.E., Rey, E., Lian, M.G., \& Morreau, L.E. (1998). The effect of creative drama and social and oral language skills of children with learning disabilities. Youth Thearre Journal, (ERIC Document Reproduction Service No. EJ607791).

Dikmeer, İ.A. (1997). Sosyal beceri eğitiminin içedönük ergenlerin içedöniiklïk düzeyine etkisi. Yayımlanmamıs yüksek lisans tezi, Ankara: Ankara Üniversitesi.

Dubow., E.F., \& Tisak, J. (1989). The relation between stressful life events and adjustment in elemantary school children: The role of social support and social problem-solving skills. Child Development, $60,1412-1423$.

Elliot, S.N., \& Gresham, F.M. (1987). Children's social skills: Assessment and classification practices. Journal of Counseling and Development, 1(66), 96-99.

Elliot, S.N., \& Gresham, F.M. (1993). Social skills interventions for children. Behavior Modification, 17(3), 287-313.

Erdoğan, F. (2002). Ilköğretim ikinci kademe öğrencilerinde sosyal becerilerin sosyo-ekonomik dïzey, cinsiyet ve yas ile ilişkisi. Yayımlanmamış yüksek lisans tezi, Ankara: Gazi Üniversitesi

Freeman, G. D., Sullivan, K., \& Fulton, C. R. (2003). Effects of creative drama on self-concept, social skills, and problem behavior. Journal of Educational Research, 96(3), 1-7.

Gönen, M. (Ed.) (1998). Özürlï Çocuklarda Drama ile Eğitim Programlart. Ankara: Așama Ltd. 
Gönen, M. (2001). Özïrlï çocuklarm eğitiminde drama. N. Aslan (Ed). Dramaya cok yönlï bakls, (s. 59-64), Ankara: Oluşum Tiyatrosu ve Drama Atölyesi Yayını.

Gresham, F. M. (1986). Conceptual and definitional issues in the assessment of children's social skills: Implications for classifications and training. Journal of Clinical Child Psychology, 15(1), 3-15.

Gresham, F. M. (1988). Best Practices in Social Skills Training. In A. Thomas, \& J. Grimes, (Eds). Best Practices in Schoolpsychology (pp.31-41). Washington: National Association of School Psychologist.

Gresham, F. M. (1997). Social competence and students with behavior disorders: Where we've been, where we are and where we should go. Education and Treatment of Children, 20(3), 233-250.

Gresham, F.M. \& Reschly, D.J. (1988). Issues in the conceptualization, classification and assessment of Social skills in the mildly handicapped. Advances in School Psychology, 6, 203-247.

Gresham, F.M., \& Elliot, S. (1987). The relationship between adaptive behavior and social skills: Issues in definition and assesment. The Journal of Special Education, 21(1), 167-181.

Gresham, F.M., \& Elliot, S. (1990). Social skills rating scale. American Guidence Service.

Hansen, D. J., Nangle, D. W., \& Meyer, K. A. (1998). Enhancing the effectivenes of social skills intervention with adolescence. Education and Treatment of Children, 21(4), 489-513. BED199011314.

Hedahl, G. O. (1980). The effect of creative drama and filmmaking on self-concept. Unpublished $\mathrm{PhD}$ dissertation, Minnesota: University of Minnesota (UMi, 41,0851 ).

Herbert, M. (1996). Social Skills Training For Children. Leicester: British Psychological Society Books.

Hops, H. (1983). Children's social competence and skills: Current research practices and future directions. Behavior Therapy, 14, 3-18.

İpek, A. (1998). Eğitimde dramanm zihinsel engelli çocuklarm sosyal gelişimleri üzerinde etkisinin incelenmesi. Yayımlanmamıș yüksek lisans tezi, Ankara: Hacettepe Üniversitesi,

Jahanian, S. (1997). Building bridges of understanding with creative drama strategies: An introductory manual for teachers of deaf elementary school students.
Kerr, M. M., \& Nelson, C. M. (1989). Strategies For Managing Behavior Problems in the Classroom (2 nd. Ed.). New jersey: Prentice Hall.

Klapprott, J.E. (2001). Behindertenarbeit. Retrieved 07.12.2001 from www.künstlerkontakte.de

Knapczyk, D.R., \& Rodes, P.G. (1996). Teaching social competence-a practical approach for improving social skills in students at-risk. Pasific Grove: Brooks/Cole Publishing Company.

Kocayörük, A.Y. (2000). Ilköğretim ögrencilerinin sosyal becerilerini geliştirmede dramanm etkisi. Yayımlanmamıs yüksek lisans tezi, Ankara: Ankara Ünjversitesi

Korinek, L., \& Popp, A.P. (1997). Collaborative mainstream integration of social skills with academic instruction. Preventing School Failure, 41(4), 148-153.

Matson, J. L., Heinze, A. H., Helsel, W. J., \& Kopperman, G. (1986). Assessing social behaviors in the visually handicapped: The matson evaluation of social skills with youngsters. Joumal of Clinical Child Psychology; 15(1), 78-87.

McCaslin, N. (1990), Creative Drama in The Classroom. (Sth ed.). London: Longman.

McFall, R. M. (1982). A review and reformulation of the concept of social skills. Behavioral Assessment, 4, $1-33$.

McGuire, J., \& Priestly, P. (1981). Life after school: A social schools curriculum. Oxford: Pergamon Press.

Merrell, K. W. (1999). Behavioral, Social And Emotional Assessment Of Children And Adolescents. London: Lawrence Erlbraum Associates, Publishers.

Merrell, K.W., \& Gimpel, G.A. (1998). Social Skills of Children And Adolescent. New Jersey: Lawrence Erlbaum Associates Inc.

Miller, H., Rynders, J.E., \& Schleinen, S.J. (1993). Drama: A medium to enhance social interaction between students with and without mental retardation. Mental Retardation, 31(4), 228-233.

Ogilvy, C. M. (1994). Social skills training with children and adolescents: A review of the evidence on effectiveness. Educational Psychology, 14(1), 73-83.

Ömeroğlu, E. (1990). Anaokuluma giden 5-6 yaşındaki çocuklarm sözel yaratıcılıklartmm gelişiminde yaratıcı drama eğitiminin etkisi. Yayımlanmamış doktora tezi, Ankara: Hacettepe Üniversitesi.

Ömeroğlu, E. (1992).Okul öncesi işitme engelli çocukların kaynaştırılmasında yaratıcı drama eğitiminin kullanılması. Çăgdaş Ĕ̆itim Dergisi, 175, 31-33. 
Parke, R. D., Harsman, K., \& Robert, B. ( 1998). Social relationship and academic success. Trust for Educational Leadership, 28(1), 32-34,

Riggio, R.E. (1986). Assessment of basic social skills. Journal of Personality and Social Psychology, 51(3), 649- 660.

San, ì. (1991). Eğittimde Drama. TED ìlkokul Öğretmenlerine Yönelik Eğitinde Drama Semineri Açıs Konussması, Ankara.

San, İ. (1996). Yaratıcılığı geliştiren bir yöntem ve yaratıcı bireyi yetiştiren bir disiplin: Eğitsel yaratıcı drama. Yeni Türkiye Dergisi, 2(7), 148-160.

Schneider, B. H. (1993). Children's Social Competence in Context-the Contributions of Family, Schools and Culture. New York: Pergamon Press.

Shepherd, G. (1983). Introduction. Developments in Social Skills Training.(I-17). S.Spence \& G. Shepherd (Eds.), New York: Academic Press.
Sorias, O. (1986). Sosyal beceriler ve değerlendirme yöntemleri. Psikoloji Dergisi, 5 (20), 24-29.

Sukerman, T. (2000). The problems of the socialization of the upper-grade students of special schools for children with hearing disabilities. Russian Education and Society, 42(5), 56-66.

Sunhi, B. (1999). Relationship between inappropriate behaviors and other factors in young children with visual impairments. Review, 3l(2),84-9l,

Tüy, S.P. (1999). İsitme engelli ve işiten çocuklarm sosyal beceriler ve problem dawranşlar yönünden karşılaş̧trılması. Yayımlanmamış yüksek lisans tezi, Ankara: Ankara Üniversitesi.

Verduyn, C. M., \& Forrest, G. C. (1990). Social training in school: An evaluation study. Journal of Adolescence, 13, 25-44.

Westwood, P. (1993). Commonsense Methods for Children With Special Needs Strategies for the Regular Classroom. London. 


\title{
Summary Social Competency, Social Skills, and Creative Drama
}

\author{
Fatma ÖNALAN AKFIRAT* \\ Ministry of Education
}

\section{Social Competency}

It is not always easy to distinguish between the concepts of social competency and social skills. Even though these concepts are used interchangeably, it has been stated that they are multi-dimensional, interrelated, but also independent constructs (Bacanl1, 1999; Elliott ve Gresham, 1993; Merrel ve Gimpel, 1998).

According to Mc Farrel (1982) social skills are certain behaviors that must be performed by individuals to show that the roles given by the society have been fulfilled. On the other hand, social competency is the evaluations based on the outcomes and judgments that show an individual has fulfilled these roles adequately. These judgments are generally based on the opinions of significant others (family, friends, teachers) or a norm group or the comparisons with any other criterion.

Social competency comprises such verbal and nonverbal behaviors as using gestures and $\mathrm{mi}-$ mics, interpreting body language, speaking in the classroom about the things happening at the moment, and participating in the discussions. The ability to perform these behaviors in an accurate way determines the social competency of the students. As a term, social competency is more broad and comprehensive than social skills just because it doesn't only imply different actions or skills. Rather, it covers all the features and comformity of the behaviors performed by the students in their interactions. To be considered socially competent the students must be competent in such individual skills and activities as starting a conversation; supporting others; adjusting to the environment; keeping on an interaction; and not doing the things they don't want to do. These skills enable them to be socially acceptable and to interact in a personally satisfying way.

\section{Social Skills}

Defined as the ability to behave in conformity with the social environment, social skills play an important role in the development of satisfying interpersonal relationships and the fulfilment of the social roles. Bacanlı (1999) states that there is not any agreement on what the social skills are; what they are comprised of (which behaviors and skills); and what their characteristics and conditions are. It is evident that it is a complex concept defined differently by the professionals just as the social competency.

Gresham and Reschly (1988) have classified the definitions of social skills under three headings in the literature. These are the definitions based on peer acceptance, behaviors and social validity. The definiton of peer acceptance is based on the assertion that peer acceptance or popularity is the indicator of social skills. It is assumed that the children and adolescents accep- 
ted by their peers are the ones who have the social skills. However, this definition cannot identify which behaviors enable the individuals to be accepted by others or to be popular in a group. Behavioral definition accepts the idea that social skills are contextual behaviors that increase the probability of reinforcing or decrease the probability of punishing the social behaviors of an individual. With this definition the beginning and the outcomes of social behaviors have been identified for evaluation and improvement purposes and made more functional. Social validity definition suggests that social skills are the behaviors that help the child predict important social situations under certain conditions. These important outcomes are the peer acceptance or popularity; the judgments of significant others about the social skills of the child; and other social skills relevant to peer acceptance and the judgments of the significant others.

\section{Social Skills Training}

Social skills training is a performance based training method aimed at helping individuals gain social skills; mostly based on behavioral techniques and utilized in groups or on individual basis (Shepherd, 1983). Social skills are teachable behaviors and they can be gained by children with disabilities or problems through an appropriate training process (Gresham, 1997). Aiming at helping the individual gain the skills identified as inadequate in a systematic way, social skills training intends to enable people to develop relationship skills, adjust to the environment they live in and increase their quality of life (McGuire ve Priestley, 1981).

Some methods used in social skills training are modeling, leadership, behavioral rehearsalrole playing, feedback, practice-generalization, social perception, emotions, and homework (Cartledge ve Milburn, 1983; Cartledge ve Milburn, 1986; Gresham, 1988; Herbert, 1996; Kerr ve Nelson, 1989). It is also stated that creative drama can be used in social skills training as a method (Barnes, 1998; De La Cruz, Rey, Lian ve Morreau, 1998; Freeman, Sullivan, ve Fulton, 2003; Gresham, 1988; İpek, 1998; Klapprott, 2001).

\section{Creative Drama}

The techniques utilized in social skills training are modeling, leadership, behavioral rehearsalrole playing, feedback, practice-generalization, social perception, emotions and homework. Creative drama is generally comprised of these techniques and includes the cognitive, affective and behavioral dimensions of education. During creative drama activities, as an experiential learning process, the participants have the opportunity to learn of themselves and others; to recognize the similarities and differences between themselves and others; to cooperate and share in the group; to think interdependently and independently in the group; to make critics about the self and the others; to develop the skills to speak, listen, read and write; to gain experience in different situations; to understand and express how to feel in different social situations and roles; to develop decision making and problem solving skills. In creative drama process, it is important for the indivuals to develop these skills by using their creativity and these skills are called as social skills.

Even though the definitions and aims of social skills training and creative drama are similar, it is evident that there is a lack of research in this area. Creative drama is a method that must be utilized effectively in social skills training since it enables the group work. 